ISSN 1112-9867

Special Issue

http://www.jfas.info

\title{
EFFECTS OF IRON SUPPLY ON THE RHEOLOGICAL PROPERTIES AND SENSORY CHARACTERISTICS OF BREAD DOUGH ENRICHED WITH MICRONUTRIENTS
}

\author{
H. Sadeghi ${ }^{1}$ and E. Eatye Salehi ${ }^{2}{ }^{*}$ \\ ${ }^{1}$ Azad University, Quchan branch, Islamic Azad university, Quchan Iran \\ ${ }^{2}$ Department of food science and technology, Quchan branch, Islamic Azad university, \\ Quchan Iran
}

Published online: 15 May 2016

\begin{abstract}
The most basic is the world wheat crops. In Iran Bread is a staple food staple Food and because, as a bearer of good food to enrich bread with iron has been considered. The effect of flour fortification star with iron, folic acid, the chemical properties (dry gluten, wet gluten, gluten-free number, protein and Ddzlny) Rheological (water absorption, resistance, expansion, loss after 10 and 20 minutes, tensile strength, capability to stretch, elasticity, Hdaksrartfa and energy of dough) bread was compared with the controls treatments were: control (no additives Flour stars), low dose (20 ppm $5.1 \mathrm{ppm}$ of iron and folic acid) average amount (30 ppm and 2 ppm iron Fūrīk acid) full amount (40 ppm 5.2 ppm of iron and folic acid). The results showed that the chemical properties, gluten-dry, wet gluten and protein were significant differences between treatments enriched bread there.
\end{abstract}

Author Correspondence, e-mail: eatayesalehi@yahoo.com doi: http://dx.doi.org/10.4314/jfas.v8i3s.177 
Rheological properties evaluated in the farinograph dough development, dough resistance, drop dough after 10 and 20 minutes have significant fluctuations. Water absorption in the samples containing significant increase in the level of 5\% is witnessed. Resistance to stretch out the dough in Extensograph 90 and 135 minutes per sample trace and the average amount compared to control a significant decrease in the level of 5 per cent, in the treatment of full value than the control and low and medium levels drop significantly at 5\% we have had. In Qabylyt to draw the opposite conclusion is true.

Keywords: iron; folic acid; flour; enriched bread.

\section{INTRODUCTION}

Wheat is one of the richest cereal in nature all the vitamins and some minerals that can be found in it. Cereals, mainly wheat, different forms, people are considered food grade is more importance and priority bread as the main food consumption considerably. Bread has long been considered one of the basic human food. Human first final for the first time, grain mixed with the water and then the resulting dough, bake bread. With the passage of time and the development of societies, bread from Central Asia and from countries such as Iran, Afghanistan and Tajikistan originated and then in South Asian countries, India and Pakistan also had expansion.About 60 percent of energy comes from crops among food so good wheat crop is unmatched.the quality of the product in different aspects of the economy is the most important meal of bread as the main strength of particular importance is Vrvzanh different groups of people. When it comes to talking micronutrients, minerals and vitamins that naturally in foods such as vegetables, dairy products, eggs, meat and poultry, seafood and vegetable seeds and defending human body play an important role.he hurt hidden Knd.grsngy "mostly due to the lack of chemical elements such as iodine, zinc, iron, folic acid and vitamin a in the human diet. the world Health organization estimates at least one of every five people in the world suffering from the lack of such elements take. Unfortunately, this dilemma that encompasses a wide range threat to health, education and economic growth, particularly in developing countries Today is considered scientifically proven that adding small amounts of iodine, zinc , vitamin a, iron and folic acid to the diet of people could be dramatic changes in 
health, ability to learn and capacity utilization they have created and the economic losses caused by micronutrient deficiencies are believed to be more than 5\% of GDPThe nutrients in the plan have been tested include whole grain flour, salt and sugar. Iran, the Middle East and North Africa the first country to iodine deficiency disorders studied and consumption of iodized salt program known as the template. So we decided to translate the first volume of a series of articles to reach readers, although small step for delivering information on this survey.from the year 1371 (1831) has begun enriching flour with vitamins B1 and Canada in 1944 significantly reduced in the region B2 enrich rice with vitamin B1 Krd.drflypyn of 1947 Shdvmtalh conducted in the years after executionDuring the research in Russia found that adding 15-35 $\mathrm{mg}$ of iron in a reduced functionality $\mathrm{kg}$ Rdmvjb gas is formed, the use of iron in ferrous sulfite is more severe than the product application..

In 2001, work flour fortification with $60 \mathrm{ppm}$ and $1.5 \mathrm{ppm}$ of elemental iron, folic acid due to the weather hot and humid area tentatively began at Bushehr.

As of August 2001, premixes containing $30 \mathrm{ppm}$ and $1.5 \mathrm{ppm}$ ferrous sulfate folic acid to flour appropriate Iran, were produced locally in the domestic pharmaceutical companies.

In January 2005 began the first phase in the Gulf region that covers 4 million people.

The second phase of flour fortification in three provinces of Kerman, Hormozgan and Golestan expand, 16 million women of childbearing age helps.

\section{Overview of food fortification with folic acid and iron}

In January of 1998, enriched cereal-grain products with folic acid (Ptrvyyl glutamic acid) in the amount of 140 micrograms per 100 grams mandatory. Range of bean-grain enriched by the FDA for all grain products, ranging from 100 to 300 micrograms per 100 grams was announced.

Several years after mandatory fortification was introduced in the United States, found that the rich products of Ghlat- Pzhvshgran bean producers too much folic acid is added by manufacturers. The justification of this practice is that adding the vitamin, reducing it during the manufacturing process and maintenance of the product, the compensation so that the nutrients shown on the label be guaranteed.

So far, three main ways to increase folate intake in the body, is known: 
1. The consumption of fresh vegetables and legumes

2. The consumption of foods rich with folic acid

3. The use of folic acid supplements

Enriched grains with folate, primarily in the form of folic acid are available. Folate concentrations were measured in several specific food preparations 5 to 37 times higher than the reported values. These high amounts of wheat flour fortification with folic acid and its use in these types of foods were considered. Enriched grain products in several countries including the US and Canada has been delivered. However, Rdgndm enriched with folic acid and iron for the general population, a risk of adverse effects due to the inhibition of vitamin B12 as well as folic acid on cancer risk are unclear role, is not recommended. However, large-scale food fortification with folic acid through diet plays an important role as a food supplement in the diet plays.

Other rich foods such as fruit juices and flour with folic acid is considered today. A daily intake of $100 \mathrm{~g}$ of product fortified with folate, provides minimum requirements for its absorption. However, only 12 micrograms is recommended for pregnant women.

\section{Effect of various processes on the stability of folic acid}

The researchers found that the degree and rate of degradation under the effect of folic acid, folate derivatives, $\mathrm{PH}$ environment, type of buffer, reducing agents in the buffer, and the food system. The results show that adding ascorbic acid extraction buffer, significantly $(\mathrm{P}<0 / 05)$ better protection against oxidation of folic acid in fortified foods, provides. The degree of protection of folic acid in the samples is extracted with ascorbic an increase of about 108 to 159 shows percentage in rich products. Researchers have reported that tetrahydrofolic activity without ascorbic acid solution folate when it was autoclaved (at 121 degrees for 12 to 15 minutes), completely stopped. But in the same condition when a percentage of ascorbic acid was added to the solution folate activity was retained at $67 \%$. On the other hand observed that the protection of folic acid, iron salts, if added to food systems, increases. Under neutral to alkaline, folic acid, and carbonate solubility and high stability in alkaline solutions showed Hydrvksydaz. For example, in aqueous solutions, folic acid at 100 degrees for 10 hours in the range of PH 5 to 12 remain stable provided that it be protected from exposure to light. But 
when the $\mathrm{PH}$ is below 5\%, folic acid dramatically loses its stability. Drastically reducing the stability of folic acid have been reported with increasing acidity. Edible gum to encapsulate folic acid, as a single polymer or polymer composition were evaluated. For example, the researchers show that folic acid encapsulated cheddar cheese over a period of three months to achieve more stability to (360 micrograms per 100 grams) of folic acid free (109 micro grams per 100 grams) showed that folic acid the risk of oxidative damage, light, heat and changing the $\mathrm{PH}$ of 7/6 is located. It is noteworthy that this causes molecular changes, to be biologically inactive forms. The amount of folic acid protected under the experimental conditions combined alginate capsules - 100 g pectin was reported in the 360 Mykrvgrmbr the ability of the capsule showed in staying healthy.

\section{RESEARCH METHODOLOGY}

Farinograph test to check the water absorption properties of dough Ryvlvzyky was performed according to AACC. Extensograph test the properties of dough Ryvlvzyky was done according to the AACC. Akstnsvgram measured by area under the curve for energy using Planimeter HAFF is done. In this study, control boxes (marked with number one) trace levels (marked with number two) treatments average value (marked with number three) Vtymarhay Prmqdar (marked with number four) are present.

1. The control, taken delivery of flour and flour obedient submissive Shirvan, without any additives.

2. Low-dose treatment, subjects' flour rich addition to this level of folic acid Bashd.hn $20 \mathrm{ppm}$ and $1.5 \mathrm{ppm}$.

3. Mean treatment, obedient addition to rich flour in the level of folic acid Bashdahn 2 ppm to $30 \mathrm{ppm}$.

4. Tymarpr amount of enriched flour Pierre-abiding In addition to this level of folic acid Bashdahn 40 ppm 2.5 ppm.

It should be noted in all laboratories, the number of repetitions is 3. Materials used in this study are as follows (Table 1). 
Table 1. Consumption in the study

\begin{tabular}{|l|l|}
\hline Materials used & Method of preparation \\
\hline Hlour same & Uf the flour sılo-abıdıng Shırvan \\
\hline Dry yeast & Freeman company Mashhad \\
\hline salt & I ncal shops \\
\hline baking soda & Local shops \\
\hline Plastıc bags & Uf flour and obedient Shirvan \\
\hline
\end{tabular}

\section{THE STATISTICAL DESIGN AND ANALYSIS OF RESULTS}

The results of this study, using software version 42/1 Mstat-c were evaluated. For this purpose, a completely randomized design was used and the samples containing different levels of iron (20, 30 and $40 \mathrm{ppm})$ and folic acid (5/1, 0/2 and 5/2 ppm) in combination with three replications preparation and the tests were carried out on them. Mean using Duncan test at the significant level of 95/0 percent (05 / OP <) were compared. Finally, Excel was used for diagramming software.

\section{RESULTS AND DISCUSSION}

The results of assessment of the chemical properties of the flour in the table below: The results show that the chemical properties, gluten-dry, wet gluten and protein rich Vtymarhay there were significant differences between the control bread gluten Ndard.dd treatments significantly increased the amount of low and medium Prmqdar samples compared to control samples to Shahddashth and enriched Daryafth Ast.dd Zeleny significant reduction in the average amount of low-enriched sample Vtymarhay not significantly different, but significant Mqdaraft Tymarpr 5 Drsdnsbt the other three show is. 
Table 2. Analysis of variance (2) the impact of different levels of iron and folic acid to wheat flour physicochemical properties

\begin{tabular}{|c|c|c|c|c|c|c|c|c|c|c|c|}
\hline \multicolumn{2}{|c|}{ Zeleny number } & \multicolumn{2}{|c|}{ Protein } & \multicolumn{2}{|c|}{ Gluten index } & \multicolumn{2}{|c|}{ Wet gluten } & \multicolumn{2}{|c|}{ Dry gluten } & \multirow{2}{*}{$\begin{array}{l}\text { Degrees } \\
\text { of } \\
\text { freedom }\end{array}$} & \multirow[b]{2}{*}{$\begin{array}{l}\text { Réferences } \\
\text { Changes }\end{array}$} \\
\hline FValue & $\begin{array}{l}\text { Mean } \\
\text { Square } \\
\end{array}$ & FValue & $\begin{array}{l}\text { Mean } \\
\text { Square } \\
\end{array}$ & $\begin{array}{c}\mathrm{F} \\
\text { Value } \\
\end{array}$ & $\begin{array}{l}\text { Mean } \\
\text { Square }\end{array}$ & $\begin{array}{c}\mathrm{F} \\
\text { Value } \\
\end{array}$ & $\begin{array}{l}\text { Mean } \\
\text { Square }\end{array}$ & $\begin{array}{c}\mathrm{F} \\
\text { Value } \\
\end{array}$ & $\begin{array}{l}\text { Mean } \\
\text { Square }\end{array}$ & & \\
\hline $\begin{array}{l}0 / 8994 \\
2 / 9755\end{array}$ & $\begin{array}{c}1 / 102^{88} \\
3 / 648^{8 *} \\
1 / 226\end{array}$ & $\begin{array}{l}1 / 5195 \\
0 / 0001\end{array}$ & $\begin{array}{c}0 / 098^{8 *} \\
0 / 000^{* *} \\
0 / 064\end{array}$ & $\begin{array}{l}0 / 4065 \\
3 / 5233\end{array}$ & $\begin{array}{c}0 / 526^{8 *} \\
4 / 558^{8 *} \\
1 / 294\end{array}$ & $\begin{array}{l}0 / 6000 \\
3 / 0000\end{array}$ & $\begin{array}{c}0 / 250^{* *} \\
1 / 250^{* *} \\
0 / 417\end{array}$ & $\begin{array}{l}0 / 3103 \\
0 / 0001\end{array}$ & $\begin{array}{c}0 / 007^{* *} \\
0 / 001^{* *} \\
0 / 024\end{array}$ & $\begin{array}{l}2 \\
3 \\
6\end{array}$ & $\begin{array}{c}\text { Reppeat } \\
\text { Treastment } \\
\text { Experimental } \\
\text { error }\end{array}$ \\
\hline
\end{tabular}

Table 3. the effect of different levels of iron and folic acid on properties Physicochemical wheat flour

\begin{tabular}{|c|c|c|c|c|c|c|}
\hline \multicolumn{5}{|c|}{ physicochemical properties of wheat flour } & \multirow[b]{2}{*}{$\begin{array}{l}\text { of folic } \\
\text { acid } \\
\text { (ppm) }\end{array}$} & \multirow[b]{2}{*}{$\begin{array}{l}\text { (ppm) } \\
\text { Iron }\end{array}$} \\
\hline $\begin{array}{c}\text { Zeleny } \\
\text { number } \\
\text { (Ml)) }\end{array}$ & $\begin{array}{l}\text { protein } \\
(\%)\end{array}$ & $\begin{array}{l}\text { of gluten } \\
(\%) \text { index }\end{array}$ & $\begin{array}{l}\text { Of wet } \\
(\%) \text { gluten }\end{array}$ & $\begin{array}{c}\text { Dry gluten } \\
(\%)\end{array}$ & & \\
\hline $20 / 5 \pm 0 / 5^{a}$ & $\begin{array}{c} \pm 0 / 2^{a} \\
10 / 2\end{array}$ & $\begin{array}{c} \pm 2 / 0^{\mathrm{sb}} \\
97 / 00\end{array}$ & $\begin{array}{l} \pm 0 / 50^{b} \\
26 / 50\end{array}$ & $\begin{array}{l} \pm 0 / 10^{\mathrm{z}} \\
10 / 50\end{array}$ & - & - \\
\hline $20 / 00 \pm 2 / 0^{a b}$ & $\begin{array}{c} \pm 0 / 0^{\mathrm{a}} \\
10 / 2\end{array}$ & $\begin{array}{l} \pm 0 / 3^{2} \\
98 / 30\end{array}$ & $\begin{array}{c} \pm 0 / 50^{2 b} \\
27 / 50\end{array}$ & $\begin{array}{c} \pm 0 / 17^{\mathrm{a}} \\
10 / 50\end{array}$ & $1 / 5$ & 20 \\
\hline $20 / 30 \pm 0 / 7^{\mathrm{ab}}$ & $\begin{array}{c} \pm 0 / 3^{\mathrm{a}} \\
10 / 2\end{array}$ & $\begin{array}{c} \pm 0 / 3^{\mathrm{ab}} \\
97 / 77\end{array}$ & $\begin{array}{c} \pm 0 / 00^{2 b} \\
27 / 00\end{array}$ & $\begin{array}{c} \pm 0 / 00^{2} \\
10 / 50\end{array}$ & $2 / 0$ & 30 \\
\hline $18 / 10 \pm 0 / 2^{b}$ & $\begin{array}{c} \pm 0 / 4^{a} \\
10 / 2\end{array}$ & $\begin{array}{l} \pm 0 / 5^{b} \\
95 / 47\end{array}$ & $\begin{array}{c} \pm 0 / 10^{2} \\
28 / 00\end{array}$ & $\begin{array}{c} \pm 0 / 02^{\mathrm{a}} \\
10 / 50\end{array}$ & $2 / 5$ & 40 \\
\hline
\end{tabular}

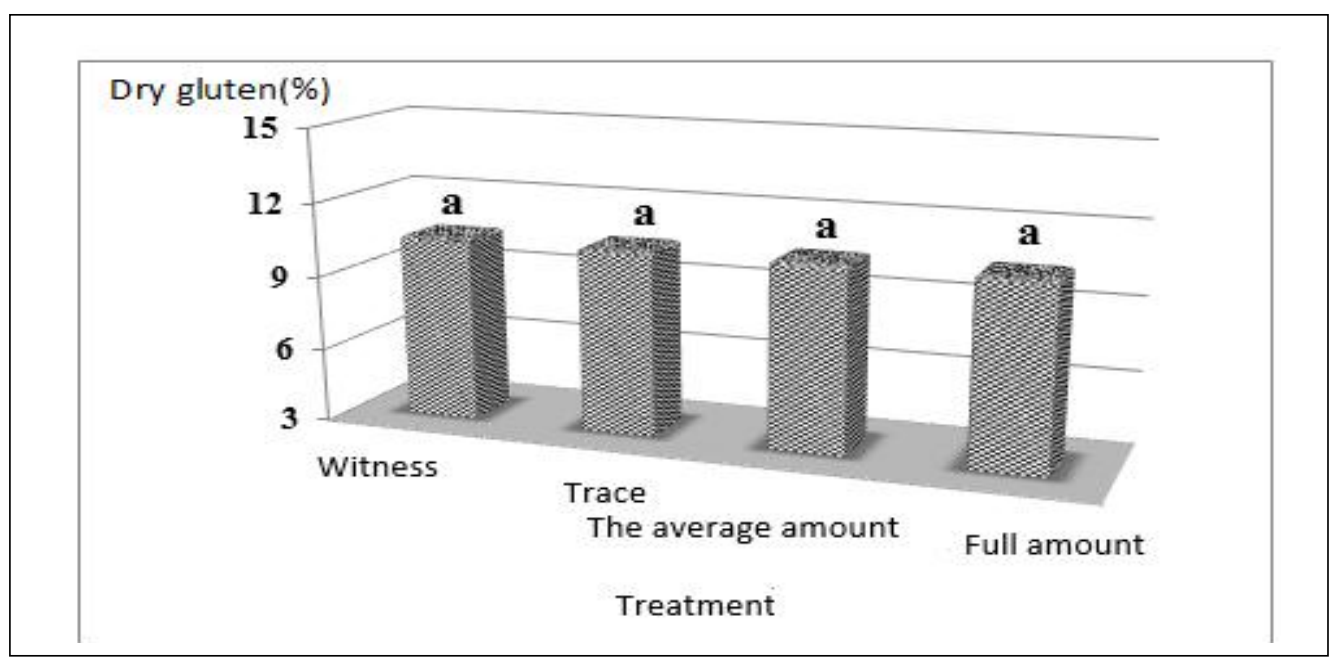

Fig.1. The effect of different levels of iron and folic acid on the gluten Dry wheat

flour (Control: without additives, low-value $20 \mathrm{ppm}$ and $5.1 \mathrm{ppm}$ iron, folic acid,The average value of $30 \mathrm{ppm}$ and $0.2 \mathrm{ppm}$ iron and Prmqdar Fūrīk acid: 40 ppm $5.2 \mathrm{ppm}$ of iron and folic acid) (Similar letters statistically at $\mathrm{P}<0.05$ difference not significant) 


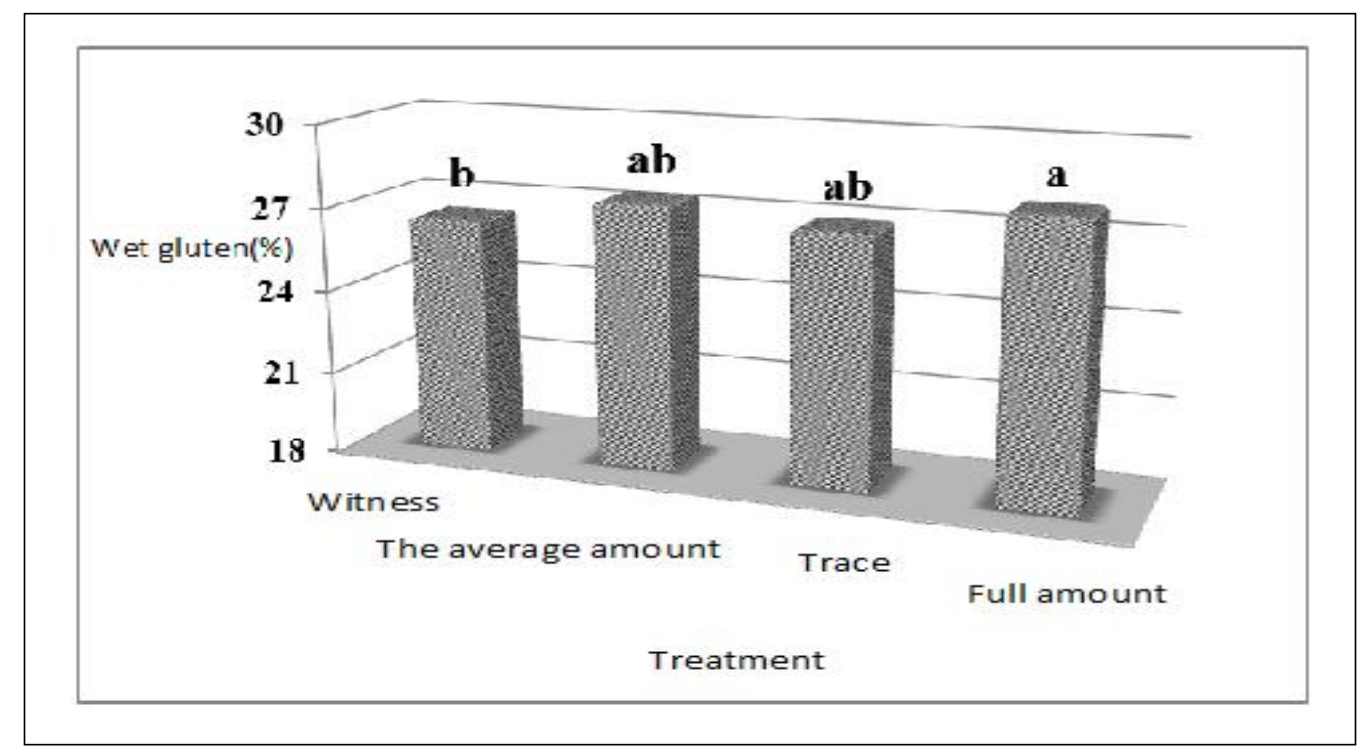

Fig.2. The effect of different levels of iron and folic acid wet gluten in wheat flour

(Control: without additives, low-value $20 \mathrm{ppm}$ and $5.1 \mathrm{ppm}$ iron, folic acids, the average value of 30 ppm and 0.2 ppm iron acid Fūrīk and Prmqdar: 40 ppm 5.2 ppm of iron and folic acid) (Similar letters statistically at $\mathrm{P}<0.05$ difference not significant)

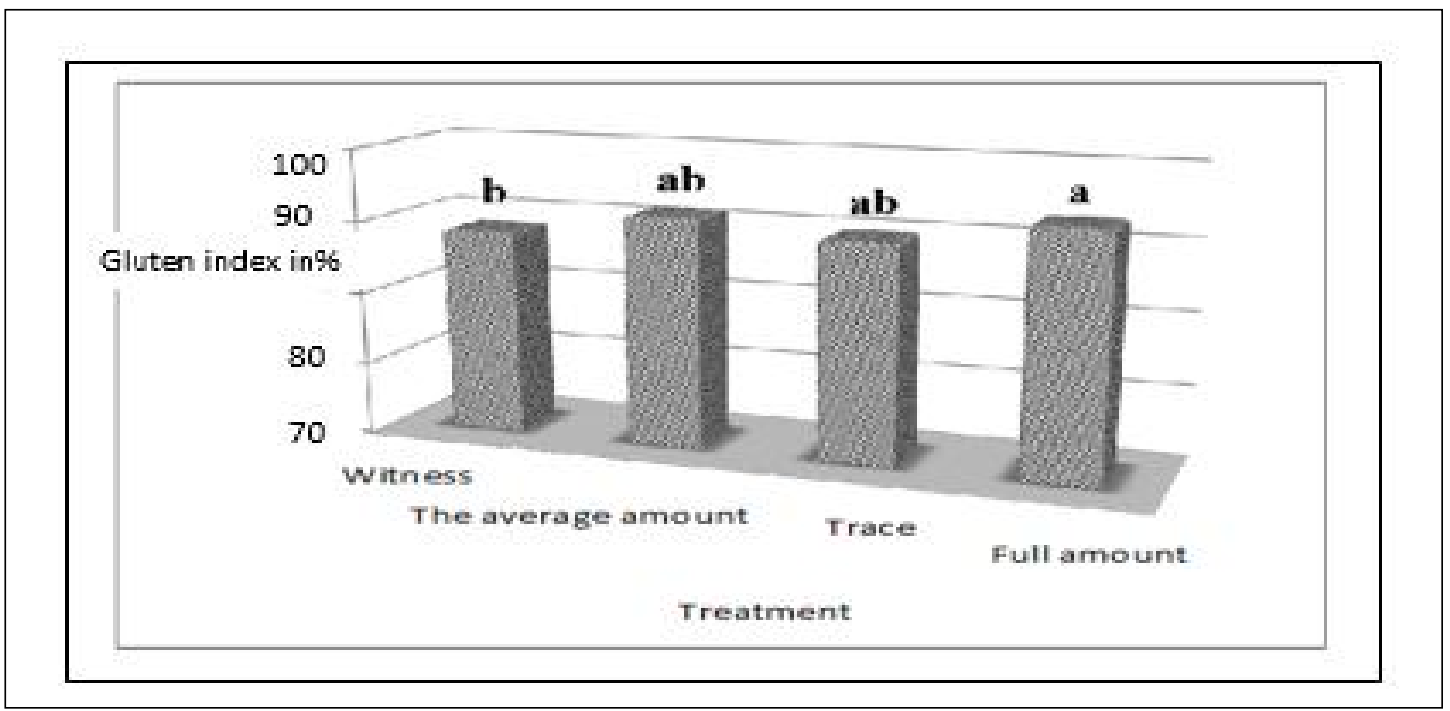

Fig.3. The effect of different levels of iron and folic acid to wheat flour in gluten index.

(Control: without additives, low-value $20 \mathrm{ppm}$ and $5.1 \mathrm{ppm}$ iron, folic acid,

The average value of 30 ppm and 0.2 ppm iron and Prmqdar Fūrīk acid: 40 ppm 5.2 ppm of iron and folic acid)

(Similar letters statistically at $\mathrm{P}<0.05$ difference not significant) 


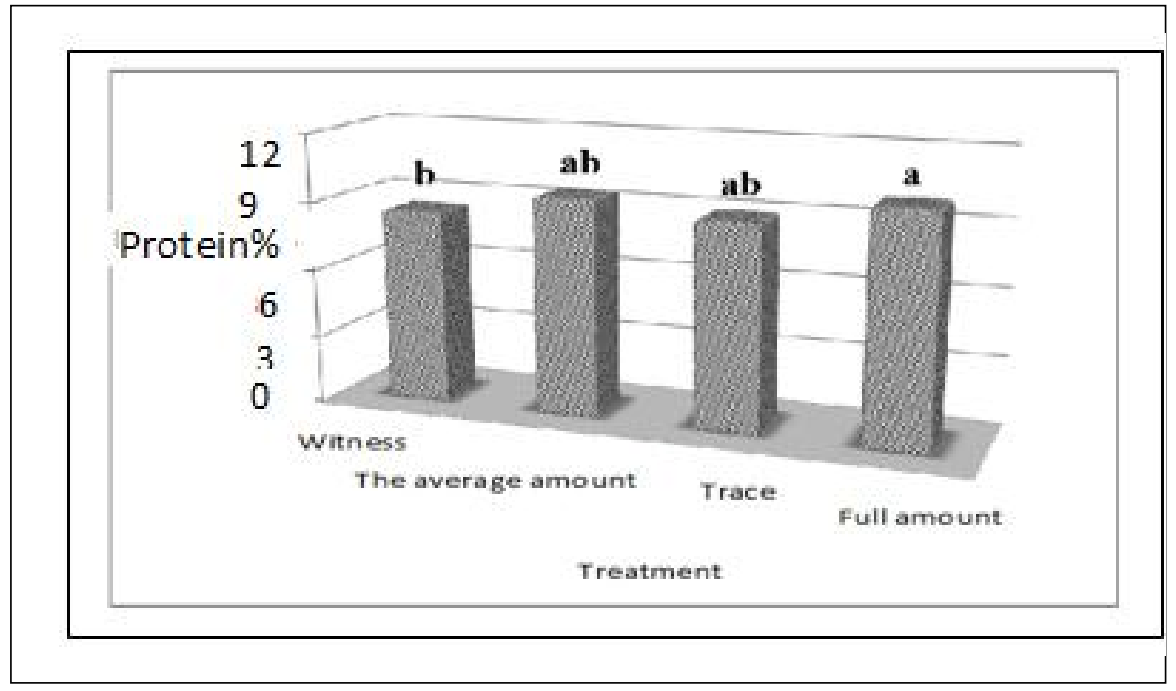

Fig.4. the effect of different levels of iron and folic acid on the protein content of wheat flour (Control: without additives, low-value 20 ppm and $5.1 \mathrm{ppm}$ iron, folic acid,

The average value of 30 ppm and 0.2 ppm iron and Prmqdar Fūrīk acid: 40 ppm 5.2 ppm of

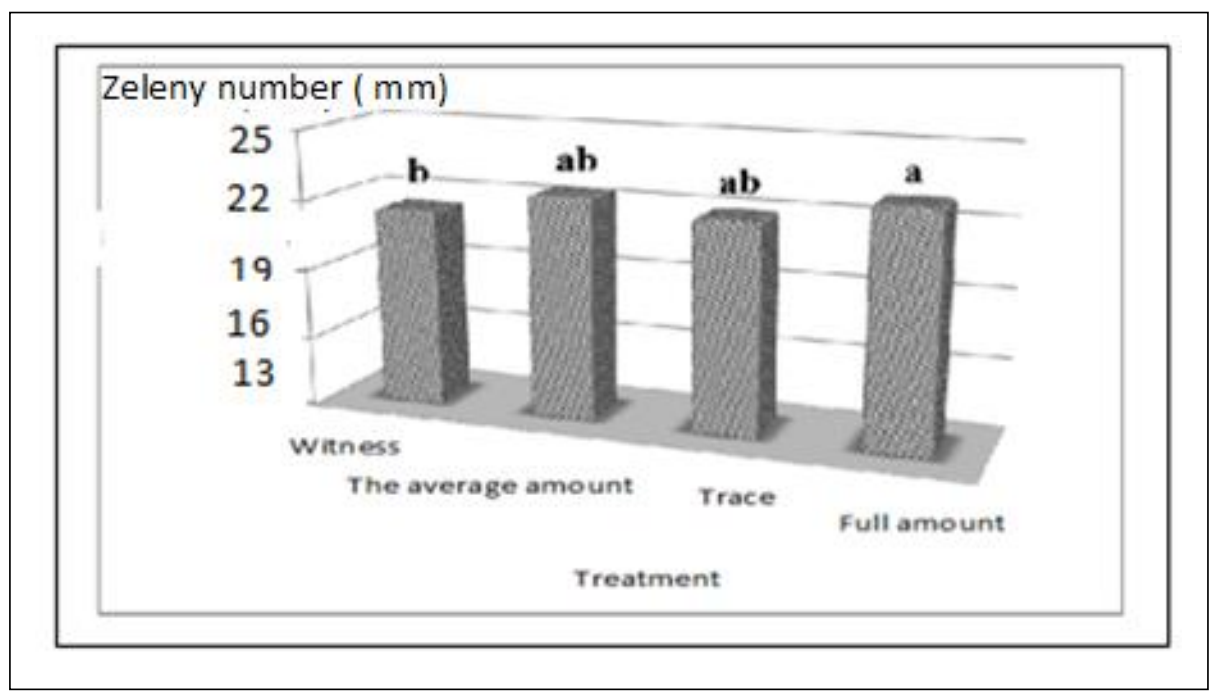

Fig.5. The effects of different levels of iron and folic acid to wheat flour in Zeleny number.

(Control: without additives, low-value 20 ppm and $5.1 \mathrm{ppm}$ iron, folic acid,

The average value of $30 \mathrm{ppm}$ and 0.2 ppm iron and Prmqdar Fūrīk acid: 40 ppm 5.2 ppm of iron and folic acid)

(Similar letters statistically at $\mathrm{P}<0.05$ difference not significant) 


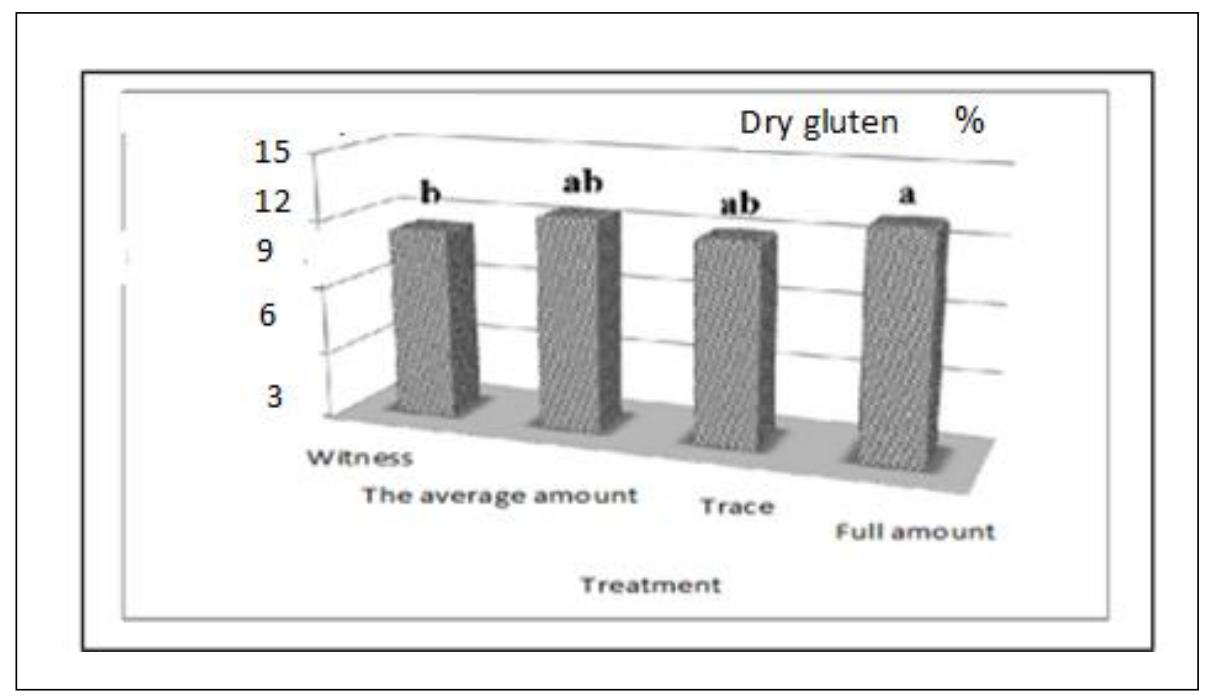

Fig.6. The effect of different levels of iron and folic acid on dry gluten content of wheat flour

Table 4. The effect of different levels of iron and folic acid on properties Farinograph dough

\begin{tabular}{|c|c|c|c|c|c|c|c|c|c|c|c|}
\hline \multicolumn{2}{|c|}{ Drop dough (20 minutes) } & \multicolumn{2}{|c|}{$\begin{array}{l}\text { Drop dough (100 } \\
\text { minutes) }\end{array}$} & \multicolumn{2}{|c|}{ Paste resistance } & \multicolumn{2}{|c|}{$\begin{array}{l}\text { Dough development } \\
\text { time }\end{array}$} & \multicolumn{2}{|c|}{ Water absorption } & \multirow{2}{*}{$\begin{array}{l}\text { Degree } \\
\text { sof } \\
\text { freedo } \\
m\end{array}$} & \multirow{2}{*}{$\begin{array}{l}\text { Sources } \\
\text { of } \\
\text { changes }\end{array}$} \\
\hline F Value & $\begin{array}{l}\text { Mean } \\
\text { Square }\end{array}$ & F Value & $\begin{array}{l}\text { Mean } \\
\text { Square }\end{array}$ & $\begin{array}{c}\text { F } \\
\text { Value }\end{array}$ & $\begin{array}{l}\text { Mean } \\
\text { Square }\end{array}$ & $\begin{array}{c}\mathrm{F} \\
\text { Value }\end{array}$ & $\begin{array}{l}\text { Mean } \\
\text { Square }\end{array}$ & $\begin{array}{c}\mathrm{F} \\
\text { Value }\end{array}$ & $\begin{array}{l}\text { Mean } \\
\text { Square }\end{array}$ & & \\
\hline $\begin{array}{c}0 / 0400 \\
7 / 2800 \\
3\end{array}$ & $\begin{array}{c}0 / 083^{* 8} \\
152 / 667^{* *} \\
2 / 083\end{array}$ & $\begin{array}{c}0 / 0545 \\
30 / 0182\end{array}$ & $\begin{array}{c}0 / 083^{* *} \\
45 / 861^{* 8} \\
1 / 528\end{array}$ & $\begin{array}{l}1 / 1143 \\
162 / 39\end{array}$ & $\begin{array}{c}1 / 011^{*} \\
* \\
1 / 579^{*} \\
* \\
0 / 010\end{array}$ & $\begin{array}{l}0 / 4667 \\
4 / 8667\end{array}$ & $\begin{array}{c}0 / 006^{* *} \\
0 / 061^{* *} \\
0 / 013\end{array}$ & $\begin{array}{l}6 / 6585 \\
216 / 78\end{array}$ & $\begin{array}{c}0 / 076^{* *} \\
2 / 469^{* *} \\
0 / 011\end{array}$ & $\begin{array}{l}2 \\
3 \\
6\end{array}$ & نكراد \\
\hline 3 & & & $\mathrm{P}<0.01^{* *}$ & $\mathrm{P}<0$. & & & & $5^{\text {ns }}$ & & & \\
\hline
\end{tabular}

Table 5. The effect of different levels of iron and folic acid on the properties of dough farinograph

Farinographic properties of dough.

\begin{tabular}{|c|c|c|c|c|c|}
\hline weight loss & weight loss & dough & of the & & Foli \\
\hline & & strength & dough & & acid \\
\hline (single & (single & $(\min )$ & (minutes) & absorption & (ppm) \\
\hline Brabndr) & Brabndr) & & & & \\
\hline
\end{tabular}

$\pm 1 / 00^{\mathrm{c}} \quad 46 / 33 \pm 0 / 58^{\mathrm{c}} \quad \pm 0 / 06^{\mathrm{d}} \quad \pm 0 / 15^{\mathrm{a}} \quad \pm 0 / 06^{\mathrm{c}}$




\begin{tabular}{ccccccc}
\hline $78 / 00$ & $5 / 27$ & $1 / 73$ & $56 / 43$ & & \\
$\pm 0 / 58^{\mathrm{b}}$ & $48 / 00 \pm 1 / 00^{\mathrm{bc}}$ & $\pm 0 / 06^{\mathrm{c}}$ & $\pm 0 / 00^{\mathrm{ab}}$ & $\pm 0 / 20^{\mathrm{b}}$ & & 20 \\
$87 / 67$ & & $5 / 57$ & $1 / 50$ & $57 / 80$ & & \\
$\pm 2 / 00^{\mathrm{b}}$ & $50 / 00 \pm 1 / 00^{\mathrm{b}}$ & $\pm 0 / 10^{\mathrm{b}}$ & $\pm 0 / 10^{\mathrm{ab}}$ & $\pm 0 / 25^{\mathrm{a}}$ & & \\
$90 / 00$ & & $6 / 40$ & $1 / 60$ & $58 / 27$ & & \\
$\pm 1 / 00^{\mathrm{a}}$ & & $\pm 0 / 15^{\mathrm{a}}$ & $\pm 0 / 10^{\mathrm{b}}$ & $\pm 0 / 06^{\mathrm{a}}$ & & \\
$95 / 00$ & $55 / 33 \pm 1 / 53^{\mathrm{a}}$ & $6 / 83$ & $1 / 40$ & $58 / 43$ & & 40 \\
\hline
\end{tabular}

(Similar letters in each column are statistically at $\mathrm{P}<0.05$ significant difference

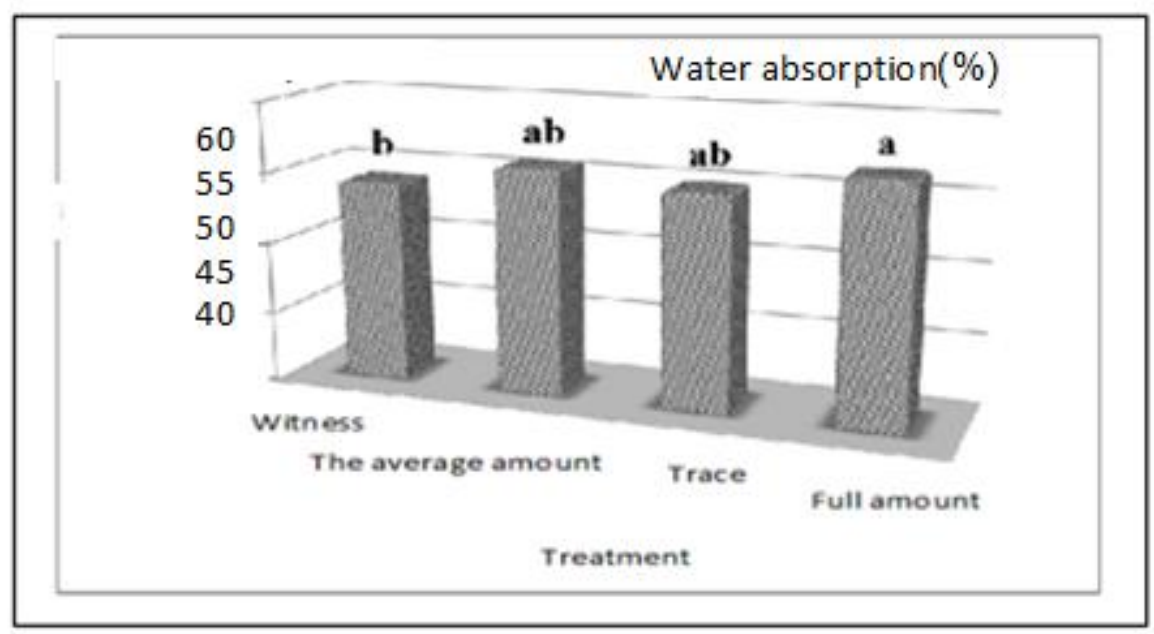

Fig.7. The effect of different levels of iron and folic acid to wheat flour water absorption in farinograph test

(Control: without additives, low-value $20 \mathrm{ppm}$ and $5.1 \mathrm{ppm}$ iron, folic acid, The average value of $30 \mathrm{ppm}$ and $0.2 \mathrm{ppm}$ iron and Prmqdar Fūrīk acid: 40 ppm 5.2 ppm of iron and folic acid)

(Similar letters statistically at $\mathrm{P}<0.05$ difference not significant)

\section{EXTENSOGRAPH 45 MINUTES}

Trace dough tensile strength compared to the control sample. This feature significantly at $5 \%$ control samples in the sample Mtvstvprmqdarnsbt less significant when Mqdarkahsh 5 Drsddashth capabilities to stretch the trace samples (120 units Brabndr) compared to control 
(130/5 Brabndr unit) significant drop 5 percent. . But treatments average and Prmqdar not significantly different from controls. In the case of resistance and the ability to stretch Khmyrhm likely due to the increased absorption of water samples for trace Asrghny, endurance, ability to stretch the dough raised below. Prmqdardrasrafzaysh Mqdarghny average of treatments proved particularly iron and low tensile strength, stretch the dough shell cased Trvbyshtrksh Ast.zryb the trace (2/6 Brabndr unit) compared to the control (2/50 Brabndr units) increased significantly at 5 Drsddashth Once cased average value (1/72 unit Brabndr) decreased significantly at 5\% compared to the low dose level of $5 \%$. This decline is significant when cased Prmqdar (1/52 Brabndr unit) will continue. paste strong correlation curve Dard.khmyr extensograph higher in some cases longer than a weak dough. in general, the maximum height is larger, more dough tensile strength. in this work, the maximum height is reduced by increasing the enrichment process allthe low cased decreased compared to the control value, which represents the area under the curve is Ndard.anrzy Bantyjh logical contradiction, either by increasing the enrichment process, meaning Dardrsth 5 per cent drop compared to the control.

Table 6. ANOVA effect of different levels of iron and folic acid extensibility featuresPaste after 45 minutes

\begin{tabular}{|c|c|c|c|c|c|c|c|c|c|c|c|}
\hline \multicolumn{2}{|c|}{ Energy } & \multicolumn{2}{|c|}{ The maximum height } & \multicolumn{2}{|c|}{$\begin{array}{c}\text { The modulus of } \\
\text { elasticity }\end{array}$} & \multicolumn{2}{|c|}{ Tensilitix } & \multicolumn{2}{|c|}{ Tensile strength } & \multirow{2}{*}{$\begin{array}{c}\text { Degree } \\
\text { sof } \\
\text { freedo } \\
m\end{array}$} & \multirow{2}{*}{$\begin{array}{l}\text { Sources of } \\
\text { changes }\end{array}$} \\
\hline F Value & $\begin{array}{l}\text { Mean } \\
\text { Sqquare }\end{array}$ & F Value & $\begin{array}{l}\text { Mean } \\
\text { Square }\end{array}$ & $\begin{array}{c}\mathrm{F} \\
\text { Value }\end{array}$ & $\begin{array}{l}\text { Mean } \\
\text { Square }\end{array}$ & $\begin{array}{c}\mathrm{F} \\
\text { Value }\end{array}$ & $\begin{array}{l}\text { Mean } \\
\text { Sqquare }\end{array}$ & $\begin{array}{c}\mathrm{F} \\
\text { Value }\end{array}$ & $\begin{array}{l}\text { Mean } \\
\text { Square }\end{array}$ & & \\
\hline $\begin{array}{l}2 / 3226 \\
114 / 47\end{array}$ & $\begin{array}{c}4 / 000^{44} \\
197 / 13944 \\
1 / 722\end{array}$ & $\begin{array}{c}903 / 0 \\
112834 / 75\end{array}$ & $\begin{array}{c}100 / 333^{44} \\
12537 / 2^{44} \\
0 / 111\end{array}$ & $\begin{array}{l}0 / 2566 \\
364 / 86\end{array}$ & $\begin{array}{c}0 / 001 * 4 \\
0 / 889 * 4 \\
0 / 002\end{array}$ & $\begin{array}{l}0 / 0380 \\
3 / 0469\end{array}$ & $\begin{array}{c}1 / 646^{44} \\
131 / 799^{4} \\
43 / 257\end{array}$ & $\begin{array}{c}/ 1054 \\
2 \\
36 / 48 \\
1\end{array}$ & $\begin{array}{c}91 / 000^{4} \\
15624 / 3 \\
44 \\
43 / 222\end{array}$ & $\begin{array}{l}2 \\
3 \\
6\end{array}$ & $\begin{array}{l}\text { Repeat } \\
\text { Treatment } \\
\text { Experimen } \\
\text { tal error }\end{array}$ \\
\hline
\end{tabular}

$\mathrm{P}<0.01^{* *} \quad \mathrm{P}<0.05^{*} \quad \mathrm{P}>0.05^{\mathrm{ws}}$


Table 7. The effect of different levels of iron and folic acid on dough extensibility characteristics after 45 minutes

\begin{tabular}{|c|c|c|c|c|c|c|}
\hline \multicolumn{5}{|c|}{ dough extensibility features ( 45 minutes) } & \multirow[b]{2}{*}{$\begin{array}{l}\text { of folic } \\
(\mathrm{ppm}) \text { acid }\end{array}$} & \multirow[b]{2}{*}{ (ppm) Irot } \\
\hline $\begin{array}{l}\text { Energy } \\
(\mathrm{Cm})\end{array}$ & $\begin{array}{l}\text { Maximum Height } \\
\text { (Brabnds unit) }\end{array}$ & $\begin{array}{l}\text { F Kshshsh } \\
\text { (Brabnds unit) }\end{array}$ & $\begin{array}{l}\text { tensility } \\
\text { (Brabndk unit) }\end{array}$ & $\begin{array}{l}\text { Tensile strength } \\
\text { (Brabndr unit) }\end{array}$ & & \\
\hline $65 / 0=1 / 0^{\mathrm{a}}$ & $380 / 0 \pm 5 / 0^{2}$ & $2 / 63 \pm 0 / 06^{2}$ & $130 / 25 \pm / 00^{2 b}$ & $330 / 0 \quad 10 \pm / 0^{\mathrm{a}}$ & - & - \\
\hline $47 / 0=2 / 0^{b}$ & $325 / 0=5 / 0^{b}$ & $2 / 47 \pm 0 / 06^{b}$ & $120 / 0 \quad 10 \pm / 0^{b}$ & $341 / 7 \quad 2 \pm / 99^{a}$ & $1 / 5$ & 20 \\
\hline $44 / 0=0 / 0^{c}$ & $264 / 7 \pm 5 / 03^{\circ}$ & $1 / 72 \pm 0 / 03^{\circ}$ & $135 / 20 \pm / 29^{a}$ & $220 / 0 \quad 10 \pm / 00^{b}$ & $2 / 0$ & 30 \\
\hline $41 / 0=1 / 0^{\mathrm{d}}$ & $234 / 7 \pm 5 / 03^{d}$ & $1 / 53=0 / 03^{d}$ & $132 / 52 \pm / 50^{\mathrm{ab}}$ & $203 / 3 \quad 3 \pm / 51^{c}$ & $2 / 5$ & 40 \\
\hline
\end{tabular}

(Similar letters in each column are statistically at $\mathrm{P}<0.05$ difference not significant)

\section{EXTENSOGRAPH 90 MINUTES}

Mqdarvmtvst low compared to the control sample tensile strength values decreased significantly at $5 \%$ level, but significant differences between treatments in low and medium value is Darnbvdh. Prmqdar cased less than the control samples and the average value of a significant drop 5 percent've had. Darmqavmt significant reduction in tension cased trace after 90 minutes fermentation can be increased due to the effect of fermentation time was barbaric Nsbtazyf loose dough. Ability to tensile low and medium levels of volatility compared to control was non-significant. Prmqdar at 5\% significant increase compared to the control samples, treatments, and the average value is low. The process of reduction traction coefficient between the sample and the control were not significant. Probably, these changes can be caused by high amounts of iron which relaxes the dough can be attributed Vksh coming too. Maximum height in the case of low and medium value at 5\% drop compared to the control means Dardashth but the difference was not significant between the two Tymarghny. Prmqdarhm samples compared to control and other cased significant drop was observed at $5 \%$. The energy or the area under the curve downward trend. In low and medium 
levels compared to control treatments were not significant, but cased Prmqdar reduction compared to control and other treatments was significant at 5\%. A significant reduction compared to the control Drhdaksr the maximum height may be weak relative to the pulp after the addition of enrichment, too (cased Prmqdar) attributed.

Table 8. ANOVA effect of different levels of iron and folic acid on dough extensibility properties After 90 minutes

\begin{tabular}{|c|c|c|c|c|c|c|c|c|c|c|c|}
\hline \multicolumn{2}{|c|}{ Energy } & \multicolumn{2}{|c|}{ The maximum height } & \multicolumn{2}{|c|}{$\begin{array}{l}\text { The modulus of } \\
\text { elasticity }\end{array}$} & \multicolumn{2}{|c|}{ Tensilition } & \multicolumn{2}{|c|}{ Tensile strength } & \multirow{2}{*}{$\begin{array}{l}\text { Degrees } \\
\text { of } \\
\text { freedom }\end{array}$} & \multirow{2}{*}{$\begin{array}{l}\text { Sources } \\
\text { of } \\
\text { change: }\end{array}$} \\
\hline F Value & $\begin{array}{l}\text { Mean } \\
\text { Square }\end{array}$ & $\begin{array}{c}\mathrm{F} \\
\text { Value }\end{array}$ & $\begin{array}{l}\text { Mean } \\
\text { Square }\end{array}$ & $\begin{array}{c}\text { F } \\
\text { Value }\end{array}$ & $\begin{array}{l}\text { Mean } \\
\text { Square }\end{array}$ & $\begin{array}{c}\mathrm{F} \\
\text { Value }\end{array}$ & $\begin{array}{l}\text { Mean } \\
\text { Square }\end{array}$ & $\begin{array}{c}\text { F } \\
\text { Value }\end{array}$ & $\begin{array}{l}\text { Mean } \\
\text { Sqquare }\end{array}$ & & \\
\hline \multirow[t]{2}{*}{$151 / 5455$} & $\begin{array}{l}1 / 000^{4 *} \\
185 / 222 * * \\
1 / 222\end{array}$ & $\begin{array}{c}0 / 0604 \\
1543 / 1611\end{array}$ & $\begin{array}{c}0 / 250^{60} \\
6386 / 97^{\circ 4} \\
4 / 139\end{array}$ & $\begin{array}{l}1 / 0186 \\
131 / 51\end{array}$ & $\begin{array}{c}0 / 006^{40} \\
0 / 784^{\circ 6} \\
0 / 006\end{array}$ & $\begin{array}{l}7 / 4706 \\
53 / 8971\end{array}$ & $\begin{array}{c}42 / 333^{44} \\
305 / 417^{40} \\
5 / 667\end{array}$ & $\begin{array}{l}0 / 1385 \\
382 / 82\end{array}$ & $\begin{array}{c}2 / 250^{4 *} \\
6220 / 8^{4 *} \\
16 / 250\end{array}$ & $\begin{array}{l}2 \\
3 \\
6\end{array}$ & $\begin{array}{l}\text { Repeat } \\
\text { treatmers } \\
\text { error }\end{array}$ \\
\hline & & & $0<0.01^{* * *}$ & $\mathrm{P}<0$ & & & & $0.05^{\mathrm{ns}}$ & & & \\
\hline
\end{tabular}

Table 9. The effect of different levels of iron and folic acid on dough extensibility characteristics after 90 minutes

\begin{tabular}{|c|c|c|c|c|c|c|}
\hline \multicolumn{5}{|c|}{ Dough extensibility features (90 minutes) } & \multirow[b]{2}{*}{$\begin{array}{l}\text { Folic acid } \\
\text { (ppm) }\end{array}$} & \multirow[b]{2}{*}{ Iron (ppm) } \\
\hline Energy $(\mathrm{cm})$ & $\begin{array}{l}\text { The maximum } \\
\text { height (unit } \\
\text { Brabondr) }\end{array}$ & $\begin{array}{l}\text { Kssbshssh } \\
\text { coefficient (unit } \\
\text { Brabadr) }\end{array}$ & $\begin{array}{l}\text { Tensilitx (unit } \\
\text { Brabondr) }\end{array}$ & $\begin{array}{l}\text { Tensile strength } \\
\text { (unit Brabndr) }\end{array}$ & & \\
\hline $\begin{array}{c} \pm 0 / 58^{a} \\
57 / 33\end{array}$ & $416 / 3=1 / 53^{a}$ & $\begin{array}{c} \pm 0 / 06^{2} \\
2 / 87\end{array}$ & $\begin{array}{l} \pm 0 / 00^{b} \\
131 / 0\end{array}$ & $370 / 0 \pm 5 / 0^{a}$ & - & - \\
\hline $\begin{array}{c} \pm 2 / 0^{b} \\
52 / 00\end{array}$ & $376 / 7 \pm 2 / 89^{b}$ & $\begin{array}{c} \pm 0 / 06^{b} \\
2 / 63\end{array}$ & $123 / 0 \pm 3 / 0^{c}$ & $331 / 0 \pm 3 / 0^{b}$ & $1 / 5$ & 20 \\
\hline $\begin{array}{c} \pm 0 / 0^{b} \\
50 / 00\end{array}$ & $371 / 0 \pm 1 / 00^{c}$ & $\begin{array}{c} \pm 0 / 01^{b} \\
2 / 50\end{array}$ & $125 / 0 \pm 5 / 0^{c}$ & $320 / 0 \pm 1 / 0^{c}$ & $2 / 0$ & 30 \\
\hline $\begin{array}{c} \pm 0 / 58^{c} \\
38 / 67\end{array}$ & $305 / 0 \pm 1 / 00^{d}$ & $\begin{array}{c} \pm 0 / 09^{c} \\
1 / 69\end{array}$ & $145 / 3 \pm 5 / 0^{a}$ & $260 / 0 \pm 4 / 0^{d}$ & $2 / 5$ & 40 \\
\hline
\end{tabular}

(Similar letters in each column are statistically at $\mathrm{P}<0.05$ difference not significant)

\section{THE EXTENSOGRAPH 135 MINUTES}

Examples of low and medium tensile strength in comparison to the time of the $5 \%$ level 
significantly decreased. But not significant between rich Dvtymar Ast.tymar full amount other than the all three treatments had a significant drop in the level of 5 percent. of course, this was not significant fluctuations stretching And.zryb significant drop compared to control treatments enriched at 5 per cent, meaning fluctuations Darnbvdh Amabyn treatments. Maximum height of the energy curve low and medium Mqdarnsbt control samples at 5 percent means Dardadshth, but Darndashtnd.drtymar Dvtymartfavt full amount of its meaning than the others at 5 percent means Darbvdh. Reduce the maximum height of the energy curve (AUC) may be due to the effect of high amounts of iron and Tkhmyrtvlany for which relaxes the excess dough Vksh be attributed.

Table 10. ANOVA effect of different levels of iron and folic acid on dough extensibility properties After 135 minutes

\begin{tabular}{|c|c|c|c|c|c|c|c|c|c|c|c|}
\hline \multicolumn{2}{|c|}{ Energy } & \multicolumn{2}{|c|}{$\begin{array}{c}\text { The maximum } \\
\text { height }\end{array}$} & \multicolumn{2}{|c|}{$\begin{array}{c}\text { The modulus of } \\
\text { elasticity }\end{array}$} & \multicolumn{2}{|c|}{ Tensilitx } & \multicolumn{2}{|c|}{ Tensile strength } & \multirow{2}{*}{$\begin{array}{c}\text { Degrees } \\
\text { of } \\
\text { freedom }\end{array}$} & \multirow{2}{*}{$\begin{array}{c}\text { Sources } \\
\text { of } \\
\text { changes }\end{array}$} \\
\hline $\begin{array}{c}\mathrm{F} \\
\text { Value }\end{array}$ & $\begin{array}{l}\text { Mean } \\
\text { Square }\end{array}$ & $\begin{array}{c}\text { F } \\
\text { Value }\end{array}$ & $\begin{array}{l}\text { Mean } \\
\text { Square }\end{array}$ & $\begin{array}{c}\text { F } \\
\text { Value }\end{array}$ & $\begin{array}{l}\text { Mean } \\
\text { Square }\end{array}$ & $\begin{array}{c}\mathrm{F} \\
\text { Value }\end{array}$ & $\begin{array}{l}\text { Mean } \\
\text { Square }\end{array}$ & $\begin{array}{c}\text { F } \\
\text { Value }\end{array}$ & $\begin{array}{l}\text { Mean } \\
\text { Sqquare }\end{array}$ & & \\
\hline $\begin{array}{l}2 / 3226 \\
114 / 47\end{array}$ & $\begin{array}{c}4 / 000^{40} \\
197 / 139^{46} \\
1 / 722\end{array}$ & $\begin{array}{l}4 / 2632 \\
5270 / 15\end{array}$ & $\begin{array}{c}9 / 000^{* *} \\
11125 / 9 * 4 \\
2 / 111\end{array}$ & $\begin{array}{l}0 / 2219 \\
506 / 73\end{array}$ & $\begin{array}{c}0 / 00146 \\
0 / 514^{46} \\
0 / 001\end{array}$ & $\begin{array}{c}0 / 1795 \\
39 / 8205\end{array}$ & $\begin{array}{c}0 / 583^{40} \\
129 / 417^{40} \\
3 / 250\end{array}$ & $\begin{array}{l}0 / 0717 \\
643 / 21\end{array}$ & $\begin{array}{c}0 / 583^{* 4} \\
5234 / 9^{* 4} \\
8 / 139\end{array}$ & $\begin{array}{l}2 \\
3 \\
6\end{array}$ & 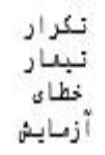 \\
\hline
\end{tabular}

Table 11. The effect of different levels of iron and folic acid on dough extensibility characteristics after 135 minutes, Same letters in each column are statistically at $\mathrm{P}<0.05$ difference not significant)

\begin{tabular}{|c|c|c|c|c|c|c|}
\hline \multicolumn{5}{|c|}{ Dough extensibility characteristics (135 minutes) } & \multirow[b]{2}{*}{$\begin{array}{c}\text { Folic acid } \\
\text { (ppm) }\end{array}$} & \multirow[b]{2}{*}{ Iron (ppm) } \\
\hline $\begin{array}{l}\text { Energy } \\
(\mathrm{Cm})\end{array}$ & $\begin{array}{l}\text { Maximum } \\
\text { Height (Brabndr } \\
\text { unit) }\end{array}$ & $\begin{array}{l}\text { F Ksbshbsh } \\
\text { (Brabodr. } \\
\text { unit) }\end{array}$ & $\begin{array}{c}\text { tensility(Brabndr } \\
\text { unit) }\end{array}$ & $\begin{array}{c}\text { Tensile } \\
\text { strength(Brabondr } \\
\text { unit) }\end{array}$ & & \\
\hline $\begin{array}{c} \pm 1 / 53^{a} \\
51 / 67\end{array}$ & $\begin{array}{c} \pm 1 / 53^{a} \\
401 / 3\end{array}$ & $\begin{array}{c} \pm 0 / 03^{a} \\
3 / 17\end{array}$ & $120 / 0 \pm 2 / 0^{b}$ & $\begin{array}{l} \pm 4 / 51^{a} \\
350 / 7\end{array}$ & - & - \\
\hline $\begin{array}{c} \pm 0 / 5^{b} \\
45 / 50\end{array}$ & $\begin{array}{c} \pm 2 / 52^{b} \\
332 / 7\end{array}$ & $\begin{array}{c} \pm 0 / 01^{b} \\
2 / 61\end{array}$ & $129 / 0 \pm 0 / 0^{\mathrm{a}}$ & $\begin{array}{c} \pm 0 / 58^{b} \\
320 / 3\end{array}$ & $1 / 5$ & 20 \\
\hline $\begin{array}{l} \pm 0 / 5^{c} \\
41 / 50\end{array}$ & $\begin{array}{c} \pm 0 / 58^{b} \\
330 / 7\end{array}$ & $\begin{array}{c} \pm 0 / 05^{c} \\
2 / 45\end{array}$ & $121 / 7 \pm 1 / 5^{b}$ & $\begin{array}{c} \pm 0 / 58^{b} \\
320 / 7\end{array}$ & $2 / 0$ & 30 \\
\hline $\begin{array}{c} \pm 2 / 52^{\mathrm{d}} \\
32 / 33\end{array}$ & $\begin{array}{c} \pm 2 / 52^{c} \\
252 / 3\end{array}$ & $\begin{array}{c} \pm 0 / 01^{d} \\
2 / 20\end{array}$ & $113 / 0 \pm 2 / 0^{c}$ & $252 / 0 \pm 2 / 0^{c}$ & $2 / 5$ & 40 \\
\hline
\end{tabular}




\section{SENSORY PROPERTIES OF FORTIFIED FLOUR}

\section{Tasyrghny on the quality of the product}

As a rule, it is important to fortify wheat flour fortified products will not affect consumer acceptance is better that the effect of enriching the consumer seems to be evident that any specific changes in the appearance, taste price of the product or even rich By happens [12].

\section{Color and appearance}

The first appearance of each food organoleptic parameters that are of interest to consumers. So if the enrichment process causes any change in the color or appearance of the food may not be accepted by the consumer. Enrichment at levels that normally occur on wheat flour does not have any effect on the appearance of food. Almntaal iron powder may be a slight blur in the flour while high levels of riboflavin, folic acid causes yellowing of the product. However, this changes when all flour be a perfectly acceptable form of treatment. Ferrous sulfate cause any glitches in the paint is not dry wheat flour in bakery products but may cause loss of color. [12]

\section{Flavor}

The criteria used to evaluate the aroma and flavor as the standard against which to measure the color and appearance applications. Preparations consumers should not notice any change in taste or aroma-enriched product is any change in the aroma and flavor enriched product is undesirable. [12]

\section{Survival}

As a general rule, the addition of nutrients to wheat flour or corn flour should not normally be reduced shelf life. Any decrease in the shelf life of flour will reduce consumer acceptability of the product.

The main reason for the persistence of flour and fat Ransydyth the presence of soluble salts to precipitate iron and zinc. This is especially true of high extraction flour whole wheat Vbadrjh. [12]

\section{Taste, mouth feeling}

Oral tissue changes should not create any sense of Shvd.ransydyth on the aroma and flavor of mouth feeling fortified flour will affect the final. Ransyd products have unpleasant tastes 
almost like the smell of soap. [12]

\section{Sensory testing}

Much experience shows that enrichment may be without any effect on the sensory properties of products such as wheat flour, Rdzrt, cakes, instant noodles, pasta products, Dad.baayn do some nutrient made from grain that there are still certain areas have not been tested and should be tested before the start enriching public programs. [12]

\section{Reducing phytic acid}

High levels of phytic acid grains is a serious problem Shvdchrakh as a deterrent in iron absorption, Knd.danh act on some other minerals contain a percentage of whole-wheat Bashnd.kahsh the amount of phytic acid can contribute to mineral intake during Knd.tsfyh mill which has caused a significant amount of acid in the flour depending on the degree of its extraction Ftyk Yabdama Hdvd60-90 percent phytic acid remains as a strong deterrent Radard final amount depends largely on the contents of ash in the ash Dard.hrchh Bashdasyd phytic there will be fewer than wheat.

Fermentation, soaking germination of phytase activity by naturally reducing the amount of phytic acid grains found in the Grdd.yk Shvdbas fundamental solution, Phytase is another fight which must Amakhmyr before baking for as long as it's set [WORLD rested his Btvandtasyrat Dadtaanzym. during the fermentation by yeast bread, phytic acid levels somewhat closer to $85 \%$ after $60 \%$ after 2 hours of time during fermentation lower the ph Dhd.hrchh further reduces the amount of phytic acid Drmhsvlat will be reduced more so than M phytic acid to iron should be as much as 1: 1 Vyadrhalt better 5 /: 1 reduced iron Tajzb increase the molar ratio of establishing a very difficult task order to achieve a final ratio of less than 1 /. In wheat, which contains 9 /. Bashdnyaz percent to $50 \mathrm{ppm}$ iron phytic acid, phytic acid decreased 75 percent during the grinding process and reduce the cooking time. Unfortunately $75 \%$ of non-fermentative Drmhsvlat such as noodle, Vpastabrqrarkrdn is difficult ratios. [12]

\section{Test sensory properties}

Sensory evaluation using the proposed method Rajab Zadeh (1991) was performed. Judges of trained personnel in accordance with the triangular test and Gasvla and Singh (1984) were 
selected and sensory properties of bread in terms of form and shape (asymmetrical shape, rupture or loss of a piece of bread and any voids or empty spaces), the upper crust (burns, abnormal color, wrinkles and irregular) lower surface properties (burns, wrinkles and abnormal levels), density and porosity (pore unusual density and high density), hardness and a soft texture and structure (doughy or unusual softness, strength of bread, brittle), color and flavor and form (nasty taste, odor or rancidity crude or natural aroma of bread) by 10 basis Panlyst table 3-23 were evaluated. Ranged from very bad evaluation module (1) to very good (5).

Table 12. Test form panel

Please drink some water before starting the procedure, please write Panlyst sample code and number.

Number sample code Panlyst

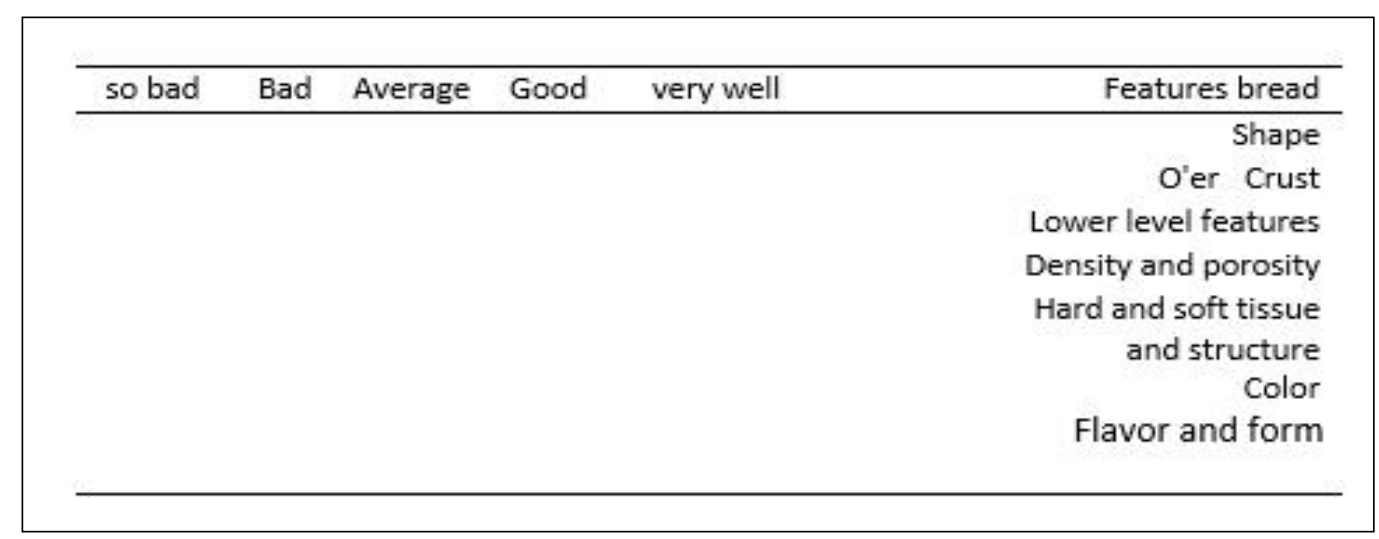

Properties have been investigated to a size not effective in sensory evaluation. So after reviewing the sources and characteristics of each coefficient ranking was given. Factor Rating traits, was included in the following table.

Table 13. Rating traits factor in sensory evaluation of bread

\begin{tabular}{|llc|}
\hline & & \\
\hline Factor Rating & \multicolumn{1}{c|}{ Features bread } \\
\hline & Form & 4 \\
& Shape & 2 \\
& The upper crust & 2 \\
& Lower level features & 2 \\
& Density and porosity & 1 \\
& Hardness and softness, & \\
& texture and structure & 2 \\
& Color & 3 \\
& Flavor and form \\
\hline
\end{tabular}


With this information, the overall acceptability of bread were calculated using the following equation.

$\mathrm{Q}=\frac{\sum(P \times G)}{\sum \mathrm{P}}$

$\mathrm{Q}=$ total acceptance bread, $\mathrm{P}=$ coefficient of rank $\mathrm{G}=$ coefficient characteristics and traits.

\section{Sensory evaluation results}

Analysis of variance effects of different levels of iron and folic acid to bread sensory properties are listed in Table 13. The impact of flour fortification of bread using a combination of sensory properties of bread such form, the characteristics of the underlying surface, surface crust, density and porosity, color, hardness, softness and structure, flavor and form, and general admission (average Total other properties according to their ratio), in table 4-12 to 4-33 and 4-26 forms is given. As that suggests the addition of these compounds to flour, due to significant differences in the $5 \%$ level in many sensory characteristics were such that by increasing the amount of these compounds in the formulation of low-dose treatment (including $20 \mathrm{ppm} 5.1 \mathrm{ppm}$ of iron and folic acid) to Prmqdar (containing $40 \mathrm{ppm} 5.2 \mathrm{ppm}$ of iron and folic acid) reduced the score by the judges taste was. It is worth noting that only the underside of the Points properties between production samples did not show significant differences $(\mathrm{P}<0.05)$.

In this regard, we can say that Prooxidants ferrous sulfate is a compound with the ability to increase spoilage is unsaturated fat rancidity. And because the flour contains little fat, the addition of ferrous sulfate can reduce shelf life. This issue is ultimately one month after the production of bread flour is used. Not a problem, but the taste of flour used in homes affected by the later maintenance. (Brass Arestani et al., 1386). However, the changes listed by the addition of iron was very small but the high sample rates reduce the amount of sensory evaluation study. Another problem with iron enriched cereals, create an unwanted color. Green or blue-green color reaction caused by grain. Ferrous sulfate particles make up dark spots in the crust. Dark red color of ferrous fumarate flour in large quantities can cause problems. This compound is also active in the dough as ferrous sulfate is soluble. Elemental 
iron powders, black color that make up dark in a little flour. The increase in these substances in the production samples with low nutritional value from sample to sample was reduced Prmqdar of the Points of colors. On the other hand, as can be seen. By increasing the amount of iron and folic acid in bread formulations of the Points of osteoporosis, and the porosity, hardness and softness, texture and structure were Kahsth. Resulting in higher housing densities was produced. This is likely due to impaired formation and maintenance Gas cells in the context of the final product. In this regard Karadzhv et al (1987) stated. The addition of 35-10 $\mathrm{mg}$ of iron in one kilogram of flour reduces the ability of the gas to be the case when using iron powder is more severe than the use of ferrous sulfite solution. The pair also acknowledged that iron powder color is darker flour. Also, with the results presented in the figure, rating the taste of the bread samples decreased with increasing enrichment. It should be noted in this context is to understand the taste, smell, and taste is a combination of the two. So taste the two major components, volatile (aroma) and non-volatile by the taste buds on the tongue felt. it depends. Various factors may release volatile components in the diet is effective in addition to taste. Many studies have been conducted to investigate these factors on flavor release (Klyandrys et al., 2008, Long et al., 2006 Baik et al. 1996). Most researchers believe that understanding the intensity of the flavor and texture of the final product depends on the type of chemical release Tmza (Bayyns and Morris, 1988). For example, in different tissues with different stiffness different sense of taste intensity has been reported (tea et al., 1991) Long et al (2004) the cause of this event in the context of similar, different interactions between materials Non taste and structure were discussed.the density of the samples has gained more and more firm texture, the more points gained in terms of taste. Finally, based on the results of the general acceptance that the sum of the results of other sensory characteristics, low-value samples Mty difference compared to control samples (no additives) in the 5\% level was the highest score to the judges taste samples, respectively. 
Table 14. Analysis of variance 19, the effect of different levels of iron and folic acid to bread ensory properties

\begin{tabular}{|c|c|c|c|c|c|c|c|c|c|}
\hline \multicolumn{2}{|c|}{$\begin{array}{l}\text { Density and } \\
\text { porosity }\end{array}$} & \multicolumn{2}{|c|}{ The upper crust } & \multicolumn{2}{|c|}{$\begin{array}{c}\text { Lower level } \\
\text { features }\end{array}$} & \multicolumn{2}{|c|}{ Shape } & \multirow{2}{*}{$\begin{array}{l}\text { Degrees } \\
\text { of } \\
\text { freedom }\end{array}$} & \multirow{2}{*}{$\begin{array}{c}\text { Sources } \\
\text { of } \\
\text { changes }\end{array}$} \\
\hline F Value & $\begin{array}{l}\text { Mean } \\
\text { Square }\end{array}$ & $\begin{array}{c}\mathrm{F} \\
\text { Value }\end{array}$ & $\begin{array}{c}\text { Mean } \\
\text { Square }\end{array}$ & $\begin{array}{c}\text { F } \\
\text { Value }\end{array}$ & $\begin{array}{l}\text { Mean } \\
\text { Square }\end{array}$ & $\begin{array}{c}\mathrm{F} \\
\text { Value }\end{array}$ & $\begin{array}{l}\text { Mean } \\
\text { Square }\end{array}$ & & \\
\hline $0 / 0000$ & $0 / 001^{* *}$ & $0 / 6923$ & $0 / 003^{* *}$ & $0 / 1579$ & $0 / 001^{* *}$ & $0 / 3750$ & $0 / 003^{* *}$ & 2 & Repeat \\
\hline \multirow[t]{3}{*}{$103 / 188$} & $0 / 459^{* *}$ & $154 / 6924$ & $0 / 559^{* *}$ & $0 / 2105$ & $0 / 001^{* *}$ & $44 / 5939$ & $0 / 396^{* *}$ & 3 & treatment \\
\hline & $0 / 004$ & & $0 / 004$ & & $0 / 005$ & & $0 / 009$ & 6 & error \\
\hline & & \multicolumn{2}{|c|}{$\mathrm{P}<0.01^{* *}$} & $.05^{*}$ & & \multicolumn{2}{|c|}{$\mathrm{P}>0.05^{\mathrm{ns}}$} & & \\
\hline
\end{tabular}

\section{CONCLUSION AND RECOMMENDATIONS}

\subsection{Discussion}

The results of this study show that the coverage of fortified flour in the province and cover 90 percent enriched bread was 7.98 percent. Golestan Province, covering 1.94\% and coverage of fortified flour fortified bread was 95 Drsdbravrd. The coating is desirable to achieve complete coverage to more closely monitor the process of flour fortification with iron to be done. In this regard, the Center for Disease Control and Prevention in the US has Nyztvsyh that the coverage of fortified flour in the world to increase the intake of iron and folic acid should be increased. These recommendations on the conditions offered that cover wheat flour fortified with iron and folic acid in the world from $18 \%$ in 2004 to $27 \%$ in 2007 reached Whereas in 2007 about 540 million people enriched flour available have had, but that ganisms appears not enough CDC2008)). It should be mentioned that the implementation of such recommendations in developing countries that have limited resources, cost-effective when the effectiveness of food fortification programs are necessary. Due to these accomplishments, it seems that the results of the implementation of flour fortification with iron Baydbh in different countries more closely studied. History implement these kinds of programs in industrialized countries has shown that food fortification a major role in reducing iron deficiency in countries like USA, Canada, UK and some European countries have. It should be noted that the success of industrialized countries in reducing iron deficiency is not 
necessarily due to the use of food fortification programs. And a variety of reasons such as economic growth and the implementation of some specific policies in health as well have been. It is the food fortification programs. In this regard it can be referred to a study done in Venezuela. The results are similar to results of evaluation of the program in Iran. Drvnzvyla indicator of iron deficiency anemia and fortify wheat flour with iron a year after the beginning of the program, has improved But about seven years after starting the program, the IDA (Kmbvdfrytyn) remained stable and anemia (low hemoglobin) increased has returned to the level before enrichment program. 4.2 Conclusion

The statistical results showed that the rheological properties and other treatments of low-value and medium of test results better than Tymarprmqdar Bvd.batvjh to be low in most treatment Mqdarvmtvst properties are not significantly different amounts, so the body needs an adequate supply in accordance with the recommendations of international organizations (FAO, WHO), the average enrichment treatment is recommended. Sensory evaluation to determine levels of control bread (flour without any additives stars) trace (5.1 ppm 20 ppm of iron and folic acid) Average amount (30 ppm and 2 ppm iron Fūrīk acid) full amount (40 ppm and 5.2 ppm iron folic acid) on external and internal features of the average amount of wheat flour dough bread Hast.ba adding external and internal features of different breads to be affectedbut compared with the control bread was recovered. It should be mentioned that the implementation of such recommendations in developing countries that have limited resources, cost-effective when the effectiveness of food fortification programs are necessary.

\subsection{Offers}

Notes that the factories producing enriched foods must observe:

Adding vitamins and minerals to foods such Yeshu feet, should be controlled carefully because these materials are strongly against oxidation, heat, light and ... Hsasbvdh and the required quantity of very small, concentrated and a very small quantity of the food and nutritional materials are increasing not only controls the quantity of added mass, these materials shall be uniform throughout the food material such Pkhshshvnd carrier. Therefore, companies need to develop methods to improve food production to the amount of vitamins and minerals in food and nutritional material for manufacturing Knnd.bdyn final production 
must meet the following points:

1. The question factories producing fortified food such, should Yshgahy test devices with the ability to analyze, control and carry food with spread legs have the presence of micronutrients. Or by a laboratory approved by the Ministry of Health to implement the cooperation agreement have clauses.

2. In the first 6 months of production of enriched products, manufacturing these products, should be monitored and controlled every week. And for the first two batches according to scientific principles and may be able to stability of micronutrients added to the end to prove its expiration date.

3. In cooperation with the Examiner Ed Yshgah outside the factory, should the contract be noted that in the first 6 months of each week at random from the production line and the final product sampling and testing is done.

4. The existence of health guidelines for sampling, the sampling time .... and the plant is necessary.

5. All the results of the micronutrients contained in the final product must once every 3 months Ykrvnvsht be submitted to regulatory agencies on the province's food.

6. You Lady factories, should all The testing was conducted and the process of registering and recording.

7. Insert the Yzmghzy existing minimum average by the end of shelf life is essential. carefully specified.

9. uniformity in Pkhshryzmghzy be observed in food.

10. You Lady factories, should the circumstances of an enrichment such as cold storage and irrigation injectors $\mathrm{m}$... to respect if necessary.

11. While all raw materials used in the enrichment of the production must have a birth certificate, vitamins and minerals to analyze and characteristics should be included in textbooks and.

\subsection{Labeling fortified foods}

In addition to the general labeling rules invoked observe the following points should be considered for fortified foods on the label: 
expressions of fortified in the criteria used in the product label.

Rich amount should be mentioned on the label and noted the following:

- Read food consumption per pack

- Consumption at every turn on Asasvzn products (for solid foods) or volume (for liquid foods)

- Calories per single use

Based on the amount and type of added micronutrients\% RNI (recommended nutrient intake) at every turn consumers if packaged food is not ready to use after mixing with water or other liquid to be procured, value added micronutrients should be \% RNI for that amount to be taken at any time to prepare to be mentioned on the label.

- If food is packed and ready for use as a raw material for preparing the food are other is used, the amount of added micronutrients as\% RNI for every 100 grams of packaged food in the form of initial and Bsv Rhett\% RNI for use in the final food after the cooking instructions should be written.

If a packaged food contains $40 \mathrm{kcal}$ per-use is final could be the amount of micronutrients Figure\% RNI per 100 kcal It noted:

Food with the phrase "containing" of a substance is labeled micronutrients should contain at least $5 \%$ (for vitamin C, 20\%) of the daily requirement per meal.

Food with the words "good source" of the nutrient labeling is Ykmadh should contain at least $10 \%$ (and for vitamin C, 35\%) of the daily requirement per meal.

Food, which means "full of" labeling will also need to contain 20 percent of the daily (and for vitamin C, 50\%) in each meal.

- The easiest way to solve the lack of Fe in society, primarily in the field of wheat enrichment and fortification of flour-is the next priority.

- According to nutritionists Nyazbdn the uptake of mineral enrichment in the fields, orchards and pastures faster and better and with higher performance takes place in the human body.

- The fifth development plan, rather than the provision of daily calories society, feed the starving population of cells enriched ways of agricultural products, targeted subsidies for the purchase of agricultural products, especially wheat based on quality Kvdhav be considered.

- Flour fortification is already being done in some parts of the country, because only involve 
Fe and folic acid can not be regarded as enrichment. Because the other Nasrmvrd needs such as zinc, calcium, magnesium, vitamins, especially vitamin D is not significant. Thus, the implementation of cell Nzrsyrshdgy although it is a step forward, but often ineffective, and should be farm or flour mills, it was done entirely using local products.

\subsection{Monitoring and Implementation}

According to the results of the corresponding series produced in this period extend it for another year.

- Monitoring compliance with appropriate labeling to prevent fraud and mislead consumers.

- In case of violations of regulations enrichment, food departments with Ystba according to the instructions and rules to do the following actions:

- The correction Tag

- The order for the above products or products with labels misleading if not corrected label

- Preventing the production and manufacturing of these products permit extension

- Announced through the media (through the Division of food, beverage and personal care Food and Drug Department).

\section{REFERENCES}

[1] Asadolahi, Sh. 2004. Exigency attention to walk movement in urban center, municipality journal, Home office, Municipal and state organization. Vol. 66, No.6.

[2] Berry, Joseph K, 1996, "Concepts, algorithms and issues in GIS", John Wiley \& Sons, New York.

[3] Grundy, A.C., C. M. Onyango, K. Phelps, R.J. Reader, J.A. Marchant, L.R. Benjamin, and A. Mead. 2005. Using a competition model to quantify the optimal trade-off between machine vision capabilities and weed removal effectiveness. Weed Research, 45: 388-405.

[4] Phillipe, R., Michel, s., Agens,v.,(2002) .Spatial databases with application to GIS. Elsevier Science, San Francisco, 3-26.

[5] Quan, Ni Fu; cheng, Cai Ming.; ping, Xu Li., wei, Fu Cheng., (2010), ComGIS-Based Water Resources Management Decision Support System, Intelligent Systems and 
Applications (ISA), and International Worksho on Digital Object Identifier,1-5.

[6] Rapport, A.1980. Pedestrian street use, Culture and perception, Public street for public use (1987), Edited by Anne Vernez Moudon, Columbia university press, New York.

[7] AACC, 2005. AACC Approved Methods St Paul, Minnesota, USA: AACC, American Association of cereal chemists.

[8] Allen, L., Benoist, B., Dary, O. and Hurrell, R., 2006. Guidelines on food fortification with micronutrients. Geneva: World Health Organization and Food and Agriculture Organization of the United Nations.

[9] Anonymus. American Association ofCreal Chemists Approved Methods,Ninth edition; 1995.

[10] Assuncao, MC. Santos, IS., Barros, AJ. Gigante, DP. And Victora, CG., 2007. Effect of iron fortification of flour on anemia in preschool children in Pelotas, Brazil. Rev Saude Publica.

[11] 19-Bakr AA. Production of iron-fortified bread employing some selected naturaliron sources. Nahrung 1997.

[12]CDC., PAHO,WHO, USAID., 2006. A2Z Project: Monitoring and Evaluating Food Fortification Programs: General Overview.

[13]Federica Balestra SSA, 2009. Empirical and fundamental mechanical tests in the evaluation ofdough and bread rheological properties Alma Mater Studiorum University Dibologna.

[14] 22-Gorton L. Leavening, s other powers.Baking and Snack 2005.

[15] J. Arcot, A.K. Shrestha, U. Gusanov, (2002). Enzyme protein binding assay fordetermining folic acid in fortified cereal foods and stability of folic acid underdifferent extraction conditions, Food Control.

[16] Janete Alaburda, Adriana P. d'Almeida, Luzia Shundo, Valter Ruvieri, Myrna Sabino, (2008). Determination of folic acid in fortified wheat flours, Journal of Food Composition and Analysis.

[17] Johnson Q, Manner V, Ranum PFortification hand book. The MicronutrientInitiative 2004; 4: 1-120.

[18] Karadzhov G, Vangelov A, Popov D. Fortofication bread with iron on basicbaking $\begin{array}{llll}\text { properties of } \quad \text { wheat } & \text { flour.auchniTroduve, }\end{array}$ 
Institute-po-Khranitelna-i-Vkusova-Promyshlennost 1987.

[19] Kelley E. Johnston, Philip A. Lofgren, Tsunenobu Tamura, (2002). Folate concentrations of fastfoods measured by trienzyme extraction method, Food Research International.

[20] Tyler V. Reducing iron deficiencythrough wheat flour fortification in The Middle-East.

[21] Wang S, Tang Y. Fortification ofcalcium and zinc in wheat flour. Journalof Zhengzhou Grain College 1995

[22] WHO., 2002a. The world health report.Reducing risks, promoting healthy life.Geneva:

[23] WHO., UNICEF, UNU., 2001b. Irondeficiency anemia: assessment, prevention, and control. A guide for program managers.Geneva, World Health Organization.

[24]Zczyk D. The physics of baking: rheological and polymer molecularstructure-function relationships in bread making. Journal of Non-newtonian FluidMechanics 2004.

\section{How to cite this article:}

Sadeghi H and Eatye Salehi E. Effects of iron supply on the rheological properties and sensory characteristics of bread dough enriched with micronutrients. J. Fundam. Appl. Sci., 2016, 8(3S), 203-229. 